\title{
Screening of white rot fungal species for their capacity to degrade lindane and other isomers of hexachlorocyclohexane $(\mathrm{HCH})$
}

\author{
Juan C. Quintero'1, María T. Moreira ${ }^{2}$, Gumersindo Feijoo², and Juan M. Lema ${ }^{2}$ \\ ${ }^{1}$ Group of Bioprocess, Department of Chemical Engineering, Universidad de Antioquia, \\ A.A. 1226, Medellín, Colombia. \\ ${ }^{2}$ Department of Chemical Engineering, School of Engineering, \\ Universidad de Santiago de Compostela, E-15782, Santiago, Spain.
}

\begin{abstract}
J.C. Quintero, M.T. Moreira, G. Feijoo, and J.M. Lema. 2008. Screening of white rot fungal species for their capacity to degrade lindane and other isomers of hexachlorocyclohexane (HCH). Cien. Inv. Agr. 35(2):159-167. White-rot fungi have demonstrated a high capacity to degrade organic pollutants, including the insecticide lindane $(\gamma-\mathrm{HCH})$. The purpose of this study was to evaluate the degradative capacities of several white rot fungi species, Bjerkandera adusta, Irpex lacteus, Lentinus tigrinus, Phanerochaete chrysosporium, Phanerochaete sordida, Phlebia radiata, Pleurotus eryngii, Poliporus cialatus, and Stereum hirsutum. Fungal tolerance to various concentrations of $\alpha-, \beta-, \gamma$ - and $\delta$ isomers of hexachlorocyclohexane $(\mathrm{HCH})$ was studied in both liquid and soil media samples. $\delta$ - and $\gamma-\mathrm{HCH}$ isomers showed the highest inhibition of fungal growth of all $\mathrm{HCH}$ isomers. P. chrysosporium and B. adusta exhibited a high tolerance to $\mathrm{HCH}$ pollution. The $\delta$ - and $\gamma-\mathrm{HCH}$ isomers were degraded between 15.1 and $70.8 \%$ by six of the nine fungal species, B. adusta, P. ciliatus, L. tigrinu, S. hirsutum, P. eryngii, and I. lacteus; $\beta-\mathrm{HCH}$ was $56.6,26.5$ and $23.9 \%$ degraded by $B$. adusta, $P$. ciliatus and P. eryngii, respectively. In nonsterile soil, all the $\mathrm{HCH}$ isomers were degraded between 8.2 and $17.5 \%$ by $B$. adusta immobilized on corncobs or woodchips. In nonsterile soil, other soil microflora showed an antagonistic effect on white-rot fungi catalyzed degradation of $\mathrm{HCH}$ isomers.
\end{abstract}

Key words: Hexachlorocyclohexane, degradation, pesticides, Bjerkandera adusta, white rot fungi.

\section{Introduction}

Hexachlorocyclohexane $(\mathrm{HCH})$ is a mixture of chemical compounds mainly formed by the following isomers: $60-70 \% \alpha-\mathrm{HCH}, 5-12 \%$ $\beta-\mathrm{HCH}, 10-12 \% \quad \gamma-\mathrm{HCH}$ and $6-10 \% \delta-\mathrm{HCH}$. $\gamma-\mathrm{HCH}$, known as lindane, has insecticidal activity and has been widely used in commercial formulations either alone or with other isomers (Breivik et al., 1999; Li, 1999). HCH isomers are recognized for their toxicity, persistence in the environment, and potential carcinogenic effects. High contamination levels are observed in some soils (Willett et al., 1998; Macrae et al., 1984). Their environmental persistence is

Received 03 December 2007. Accepted 22 April 2008.

1Corresponding author: jcquinte@udea.edu.co attributed to resistance to microbially catalyzed degradation (Alexander, 1981). The purpose of this study was to identify microbes that are capable of metabolizing $\mathrm{HCH}$ isomers.

White-rot fungi degrade environmental pollutants such as polycyclic aromatic hydrocarbons, pesticides, dyes, plastics and explosives (Aust and Benson, 1993; Field et al., 1993; Bumpus et al., 1985). These fungi possess an extracellular oxidative enzymatic system that degrades wood lignin (Tien and Kirk, 1988). Three ligninolytic enzymes, manganese peroxidase $(\mathrm{MnP})$, lignin peroxidase $(\mathrm{LiP})$ and laccase, also catalyze degradation of organic pollutants (Mester and Tien, 2000; Bucke, 1998). These enzymes are produced under nutrient-limiting conditions (Couto et al., 2002; Moreira et al., 2000). Their synthesis 
is not induced by the presence of pollutants (Barr and Aust, 1994). Cytochrome P-450 enzymes are also involved in the degradation of organochloride compounds (Masaphy et al., 1996; Mougin et al., 1996). In addition, reductive dehalogenation reactions serve to degrade organochlorine compounds (Reddy et al., 1998).

Several prior studies have reported the degradation of lindane by white-rot fungi in liquid and solid medium. However, no prior study has reported degradation of $\alpha-\beta$ - and $\delta$ - $\mathrm{HCH}$. Prior reports on the degradation of $\gamma$-HCH by Phanerochaete chrysosporium show percent decompositions between $10.6 \%$ (Arisoy, 1998) and 90\% (Singh and Kuhad, 1999), and mineralization values between $3.9 \%$ (Mougin et al., 1996) and more than $90 \%$ (Bumpus et al., 1985). In soil bioremediation assays, less $\gamma-\mathrm{HCH}$ is eliminated than in liquid medium (Mougin et al., 1997). This is due to the difference in mass transfer rates between soil and liquid. As a result of mass transfer effects, $\mathrm{HCH}$ isomers show a much slower rate of metabolism in soil than in liquid media. To increase the levels of degradation in soil, fungal species were immobilized on lignocellulosic material supports such as wood chips, corncobs, and wheat straw and then innoculated into polluted soils (Kennedy et al., 1990; Andersson and Henrysson, 1996). These cellulosic materials are a plentiful source of nutrients that favor fungal growth and soil colonization. Additionally, cellulosic substrates induce the production of ligninolytic enzymes (Quintero et al., 2006a; Castillo et al., 2001; Fujian et al., 2001).

In this study, fungal tolerance to growth in different $\mathrm{HCH}$ concentrations was measured. In addition, the degradative capacity of nine white rot fungi species toward $\alpha-, \beta-, \gamma-$ and $\delta-\mathrm{HCH}$ isomers was measured. The best strain was selected for further bioremediation studies.

\section{Materials and methods}

\section{Chemicals}

Hexachlorocyclohexane, isomers $\alpha-, \beta$ - and $\delta$ - (Riedel-de Haën-Fluka, Seelze, Germany), the isomer $\gamma$-HCH (Sigma-Aldrich, Steinheim, Germany) and Poly R-478 dye (Sigma-Aldrich) with chemical purities between 98 to $99 \%$ were used in these studies.

\section{Microorganisms and culture media}

The following fungal strains were used for screening: Bjerkandera adusta, Irpex lacteus, Lentinus tigrinus, Phanerochaete chrysosporium, Phanerochaete sordida, Phlebia radiata, Pleurotus eryngii, Poliporus cialatus and Stereum hirsutum. Isolates of these fungi were obtained from the culture collection of the Bioprocess and Environmental Engineering Group (School of Engineering, Universidad de Santiago de Compostela, España). Initially, the fungi were cultured in Petri plates containing per liter: $15 \mathrm{~g}$ agar, $3.5 \mathrm{~g}$ malt extrac, and $10 \mathrm{~g}$ glucose, $\mathrm{pH} 5.5$ (MG). The fungi were grown at $30^{\circ} \mathrm{C}$ for $5 \mathrm{~d}$ before to excise 6-mm agar plugs from colonized Petri plates and used to inoculate 1L Fernsbach flasks containing $100 \mathrm{~mL}$ culture medium containing per liter: glucose $(10 \mathrm{~g})$, peptone $(5 \mathrm{~g})$, sodium acetate $(20 \mathrm{mM}$, $\mathrm{pH} \mathrm{4.5)}$ and BIII nutrients solution $(10 \mathrm{~mL})$ (Tien and Kirk, 1988). Cultures were incubated at $30^{\circ} \mathrm{C}$ for $7 \mathrm{~d}$. Before inoculation, mycelium was blended for $60 \mathrm{~s}$ in a Waring blender.

\section{Effect of HCH isomers on fungal growth}

The fungal growth inhibitory effect of the $\mathrm{HCH}$ isomers was examined in Petri plates containing MG media with $0,1,5$ and $10 \mathrm{mg} \cdot \mathrm{L}^{-1}$ of the respective $\mathrm{HCH}$ isomer. The $\mathrm{HCH}$ isomers were prepared as stock solutions dissolved in acetone (concentration of $2 \mathrm{~g} \cdot \mathrm{L}^{-1}$ ) and added to sterilized MG media after autoclaving and cooling to $50^{\circ} \mathrm{C}$. Mycelium plugs $(6-\mathrm{mm})$ was punched from MG agar plates and placed in triplicate in the center of Petri plates. Cultures were incubated at $30^{\circ} \mathrm{C}$ and the colony diameter measured every one day for nine days.

\section{Biodegradation assays in liquid medium}

Biodegradation assays were performed in triplicate in $100 \mathrm{~mL}$ Erlenmeyer flasks containing $2 \mathrm{~mL}$ of homogenized mycelial suspensions (blended mycelium) (1.4 $\mathrm{g} \cdot \mathrm{L}^{-1}$ 
of dry biomass) and $18 \mathrm{~mL}$ of media with a composition identical to MG media except that the peptone content was reduced from 5 to 2 $\mathrm{g} \cdot \mathrm{L}^{-1}$. To each flash $25 \mu \mathrm{L}$ of a $2.0 \mathrm{~g} \cdot \mathrm{L}^{-1} \mathrm{HCH}$ stock solution (in acetone) were added to a final concentration of $2.5 \mathrm{mg} \cdot \mathrm{L}^{-1}$. Abiotic controls, without mycelial suspensions, were included to measure non-specific loss of target compounds. The cultures were incubated under continuous agitation at $150 \mathrm{rpm}$ for $10 \mathrm{~d}$ at $30^{\circ} \mathrm{C}$. Samples were withdrawn for $\mathrm{HCH}$ analysis at the beginning of the experiment and after $10 \mathrm{~d}$ of incubation.

\section{Remediation assays of $\mathrm{HCH}$ polluted soil}

Based on the screening results, B. adusta and $P$. chrysosporium were selected for remediation assays. Sandy slime soil obtained from a forest, taken at a depth of $15 \mathrm{~cm}$, was used for these experiments. Bioremediation laboratory assays were performed in triplicate in $100 \mathrm{~mL}$ Erlenmeyer flasks with $10 \mathrm{~g}$ of sterilized $\left(121^{\circ} \mathrm{C}\right.$ for $15 \mathrm{~min}$ ) or non-sterilized soil samples. Soil was contaminated with $12.5 \mu \mathrm{L}$ of $\mathrm{HCH}$ stock solution $\left(2.0 \mathrm{~g} \cdot \mathrm{L}^{-1}\right.$ of each isomer in acetone) to achieve a concentration of $2.5 \mathrm{mg} \cdot \mathrm{kg}^{-1}$ for each isomer and then inoculated with $1.25 \mathrm{~g}$ of fungus immobilized in lignocellulosic materials ( $0.5 \mathrm{~mm}$ diameter woodchips or corncobs). The cultures were incubated at $30^{\circ} \mathrm{C}$ for 5 weeks. Moisture was added once a week, by adding sterilized water according to the observed weight loss. Abiotic controls were performed mixing soil with non colonized lignocellulosic materials. For $\mathrm{HCH}$, analyses were performed in triplicate. Each of the three flasks was assayed at the beginning of the experiment and after $35 \mathrm{~d}$ of incubation.

\section{Extraction and GC-MS analysis}

$\mathrm{HCH}$ extraction of liquid and soil samples was performed by adding $20 \mathrm{~mL}$ of 1:1 hexaneacetone solution to each Erlenmeyer flask. The flasks were tightly sealed with a cap rubber and vigorously shaken for $2 \mathrm{~h}$ at $300 \mathrm{osc} \cdot \mathrm{min}^{-1}$ in an oscillating agitator. After extraction, samples were subjected to ultrasonic treatment for 15 min in order to separate the organic solid phase from aqueous phases. Then a sample of the organic solid phase was withdrawn for GC-MS analysis. Measured extraction yields for liquid medium and for soil were between $90-100 \%$ and $75-80 \%$ respectively.

Residual $\mathrm{HCH}$ and intermediate $\mathrm{HCH}-$ metabolites were analyzed in a VarianSaturn GC/MS (CP 3900) equipped with a split-splitless injection port and an automatic injector (CP-8400) and connected to an ion trap mass spectrometer (Varian Saturn 2100). A CP-Sil 8 CB Low Bleed/MS fused silica WCOT capillary column (30 m length and 0.25 $\mathrm{mm}$ ID) was used. The oven temperature was programmed as follows: hold at $60^{\circ} \mathrm{C}$ for 2 min; ramp increase rate of $20^{\circ} \mathrm{C} \cdot \mathrm{min}^{-1}$ to final temperature of $180^{\circ} \mathrm{C}$; ramp increase rate of $5^{\circ} \mathrm{C} \cdot \mathrm{min}^{-1}$ to final temperature of $200^{\circ} \mathrm{C}$ and a ramp increase rate at $10^{\circ} \mathrm{C} \cdot \mathrm{min}^{-1}$ to a final temperature of $300^{\circ} \mathrm{C}$. An injection volume of $1 \mu \mathrm{L}$ was used. The injections were made via a split-less injection at $280^{\circ} \mathrm{C}$. Helium was used as a carrier at a flow rate of $1.0 \mathrm{~mL} \cdot \mathrm{min}^{-1}$. The retention times of $\mathrm{HCH}$ isomers were: $\alpha$ $\mathrm{HCH}(8.90 \mathrm{~min}), \beta-\mathrm{HCH}$ (9.50 min), $\gamma-\mathrm{HCH}$ (9.80 $\mathrm{min})$ and $\delta$-HCH (10.60 min). $\mathrm{HCH}$ was quantified using a linear standard calibration curve with a range from 0.05 to $5 \mathrm{mg} \cdot \mathrm{L}^{-1}$. The percent biodegradation was calculated on the basis of the proportionate change between $\mathrm{HCH}$ remaining in abiotic controls and $\mathrm{HCH}$ in liquid and soil assays.

\section{Results}

\section{Effect of HCH isomers on fungal growth}

Independent of the fungi species, the $\delta-\mathrm{HCH}$ isomer had the highest detrimental effect on the mycelial growth, followed by lesser effects by $\gamma-\mathrm{HCH}, \beta-\mathrm{HCH}$ and $\alpha-\mathrm{HCH}$ isomers, respectively. There was a dose response effect with the highest mycelial growth inhibition obtained with 5 and $10 \mathrm{mg} \cdot \mathrm{L}^{-1}$ of the respective $\mathrm{HCH}$ isomers (Figure 1). A concentration of 10 $\mathrm{mg} \cdot \mathrm{L}^{-1} \delta$ - $\mathrm{HCH}$ completely inhibited mycelial growth of $S$. hirsutum, and more than $80 \%$ inhibited mycelia growth of L. tigrinus, $P$. radiata, $P$. ciliatus and $P$. sordida. At the same concentration, $\gamma-\mathrm{HCH} 60 \%$ inhibited mycelial growth of $P$. sordida, $P$. radiata and $40 \%$ inhibited mycelial growth of $B$. adusta and $P$. ciliatus. Among fungal species, $P$. 
chrysosporium and B. adusta were the most tolerant of $\mathrm{HCH}$ isomers (Figure 1).

\section{Degradation of $\mathrm{HCH}$ in liquid culture}

The highest rate of degradation of $\gamma-\mathrm{HCH}$ was obtained with B. adusta (42.4\%) and P. eryngii $(48.5 \%)$. The highest rate of degradation of $\delta$ $\mathrm{HCH}$ was obtained with $P$. eryngii (70.8\%), followed by $P$. ciliatus $(60.4 \%)$, B. adusta (54.2\%) and I. lacteus (53.8\%) (Table 1). The $\beta$-HCH isomer was the most resistant to degradation with the highest rates observed with $B$. adusta (56.6\%), followed by P. ciliatus (26.5\%) and P. eryngii (22.7\%).

In liquid medium, the concentration of $\alpha-\mathrm{HCH}$ decreased substantially and the concentration of $\gamma$-HCH showed a limited decrease. The difference between abiotic controls and fungi assays represents biological degradation. Degradation of $\alpha-\mathrm{HCH}$ was detected only with P. ciliatus (10.8\%) and P. eryngii (23.9\%).
The analysis of the $\mathrm{HCH}$ taken from samples in liquid medium showed no detectable metabolites. However, in the culture extracts of $B$. adusta, other organochloride compounds like 3-chloro-4-metoxiphenil ethanone and 2,4dichloro-3-metoxibenzene-carbonyl chloride were detected (Figure 2).

\section{Soil bioremediation assays}

For assays with $P$. chrysosporium, no degradation of pollutants was observed (Figure 3). However, fungal colonization of the soil was observed. For incubations performed with $B$. adusta, all the isomers present in the soil were between 8 and $17 \%$ degraded with woodchips and between 13 and $17 \%$ degraded with corncobs after 4 weeks incubation. An extensive colonization of the soil by fungus was observed.

To evaluate the effect of the soil microflora on the degradation of $\mathrm{HCH}$ and its possible
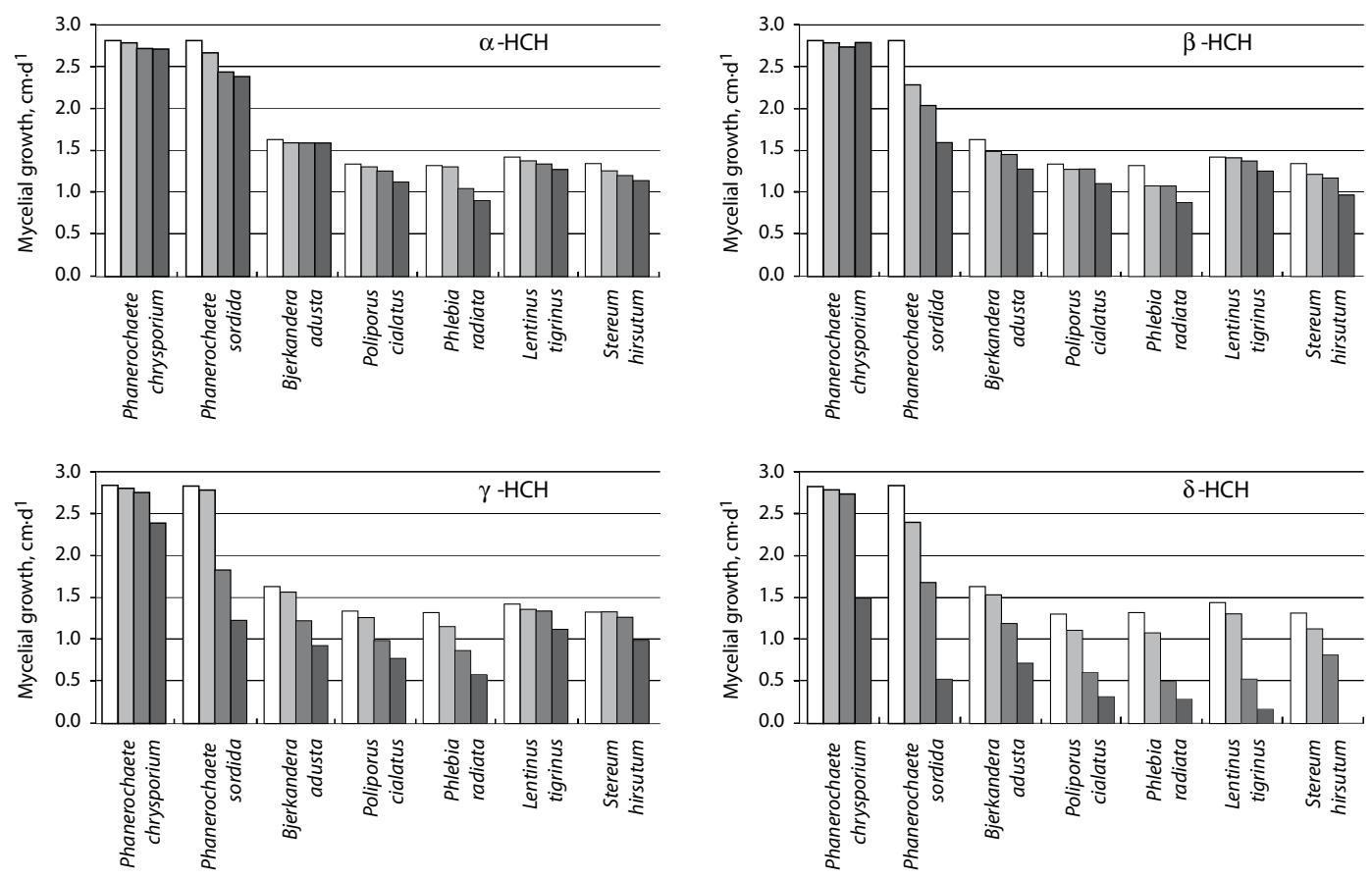

Figure 1. Effect of $\mathrm{HCH}$ isomers on mycelial growth of seven white rot fungi at $30^{\circ} \mathrm{C}$ determined in agar plates. White bar = control without $\mathrm{HCH}$, light grey bar $=1 \mathrm{mg} \cdot \mathrm{L}^{-1}$, and medium grey bar $=5 \mathrm{mg} \cdot \mathrm{L}^{-1}$, dark grey bar $=10 \mathrm{mg} \cdot \mathrm{L}^{-1}$. Standard deviation $<15 \%$ of each value. 


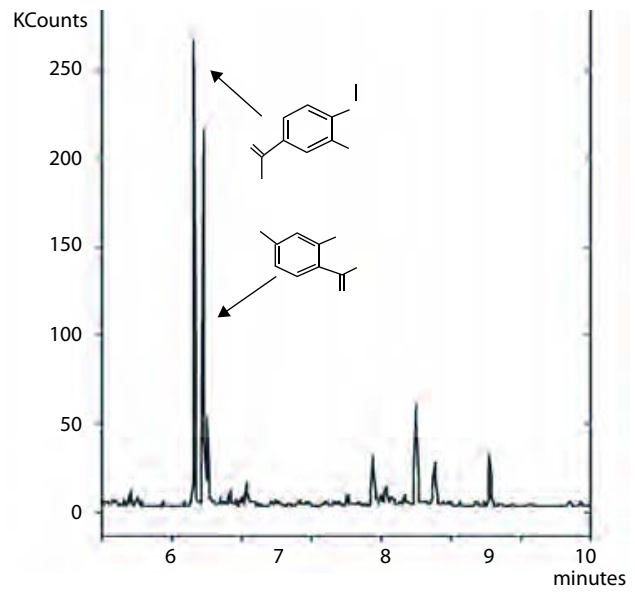

Figure 2. Chromatogram of organochloride compounds detected in the biodegradation studies of hexachlorocyclohexane $(\mathrm{HCH})$ isomers with Bjerkandera adusta in liquid medium after $10 \mathrm{~d}$ of treatment. The retention times wereasfollows: $\alpha-\mathrm{HCH}(8.90 \mathrm{~min}), \beta-\mathrm{HCH}(9.50 \mathrm{~min}), \gamma-\mathrm{HCH}$ (9.8 $\mathrm{min})$, and $\delta$ - $\mathrm{HCH}$ (10.6 min), ethanone, [1-(3-chloro-4methoxyphenyl)] (6.3 min) and 1-benzenecarbonyl chloride, (2,4-dichloro-3-methoxy) (6.5 min).

synergistic effect with the ligninolytic fungi, experimental results with sterile and unsterile soil were compared. Maximum degradations between 12 and $16 \%$ for $\alpha-\mathrm{HCH}$ and around $60 \%$ for $\gamma-\mathrm{HCH}$ were achieved after 28 days. However, for $\beta$ - and $\delta-\mathrm{HCH}$, no degradation was possible under any evaluated conditions (Table 2).

\section{Discussion}

The isomers $\gamma$ - and $\delta$ - $\mathrm{HCH}$ were substantially inhibitory to fungal growth, while $\alpha$ - and $\beta-\mathrm{HCH}$ had no detrimental effect on fungal growth at the concentrations used in this study. A similar effect was obtained in toxicity assays with methanogenic bacteria (Quintero et al., 2006b). However, growth inhibition was not observed with white-rot fungi Cyathus bulleri and Phanerochaete sordida. At $80 \mu \mathrm{g} \cdot \mathrm{L}^{-1}$ $\gamma-\mathrm{HCH}$, which was the lowest concentration studies, little or no growth inhibitory effect was observed (Singh and Kuhad, 2000). Pentachlorophenol was also highly inhibitory to fungal growth (Alleman et al., 1992). The insecticidal properties of $\gamma-\mathrm{HCH}$ explain its more negative effect on fungal growth (Willett et al., 1998). The present study is the first report of the effect of all $\mathrm{HCH}$ isomers on white rot fungi.

Several studies have reported the degradation of lindane by white-rot fungi. However, these studies lack data on degradation of $\alpha-, \beta$ - and $\delta$ $\mathrm{HCH}$ isomers. Our results showed the potential use of white-rot fungi for the degradation of $\beta$ - and $\delta$-HCH isomers, which are considered to be highly resistant to degradation both in aerobic and anaerobic conditions (Bachmann et al., 1988). The capability of white-rot fungi to degrade these isomers is demonstrated in this study.

Previous reports on the degradation of $\gamma-\mathrm{HCH}$ by

Table 1. Biodegradation of hexachlorocyclohexane $(\mathrm{HCH})$ isomers by white rot fungi after $10 \mathrm{~d}$ in liquid medium.

\begin{tabular}{lcccc}
\hline \multirow{2}{*}{ White rot fungi } & \multicolumn{4}{c}{$\mathrm{HCH}$ isomers degraded ${ }^{1} \%$} \\
\cline { 2 - 5 } & $\alpha-\mathrm{HCH}$ & $\beta-\mathrm{HCH}$ & $\gamma-\mathrm{HCH}$ & $\delta-\mathrm{HCH}$ \\
\hline Phanerochaete chrysosporium & $\mathrm{nd}$ & 0.0 & $\mathrm{nd}$ & 0.0 \\
Phanerochaete sordida & $\mathrm{nd}$ & 0.0 & $\mathrm{nd}$ & 0.0 \\
Bjerkandera adusta & $\mathrm{nd}$ & $56.6 \pm 7.1$ & $42.4 \pm 9.4$ & $54.2 \pm 12.4$ \\
Poliporus ciliatus & $10.8 \pm 2.5$ & $26.5 \pm 3.8$ & $32.5 \pm 1.8$ & $60.4 \pm 9.1$ \\
Phlebia radiata & $\mathrm{nd}$ & 0.0 & $\mathrm{nd}$ & $24.9 \pm 5.9$ \\
Lentinus tigrinus & $\mathrm{nd}$ & 0.0 & $15.1 \pm 5.1$ & $39.5 \pm 4.3$ \\
Stereum hirsutum & $\mathrm{nd}$ & 0.0 & $24.6 \pm 1.9$ & $29.9 \pm 2.5$ \\
Pleurotus eryngii & $23.9 \pm 0.5$ & $22.7 \pm 2.6$ & $48.5 \pm 0.0$ & $70.8 \pm 1.4$ \\
Irpex lacteus & nd & 0.0 & $33.7 \pm 1.3$ & $53.8 \pm 2.1$ \\
\hline
\end{tabular}

${ }^{1}$ Each value is the mean of three replicates. \pm standard deviation.

${ }^{2}$ nd: not determined. 

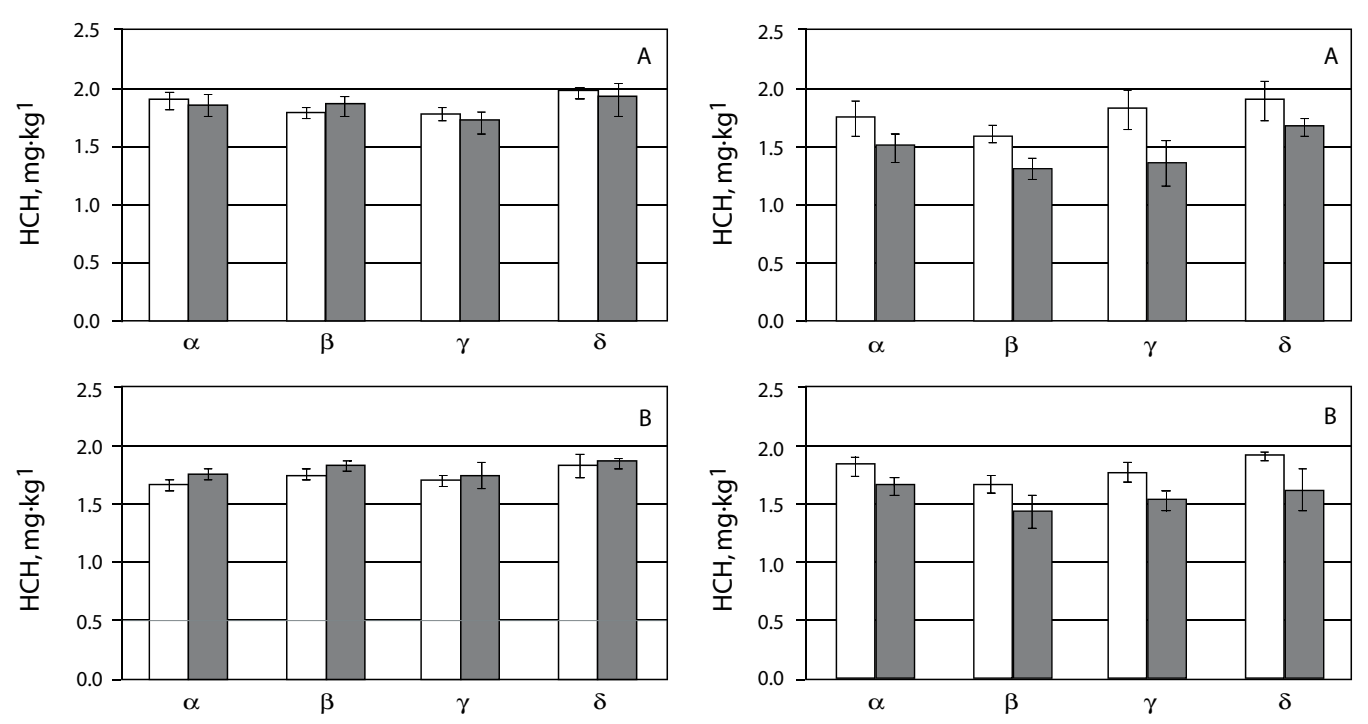

Figure 3. Biodegradation of isomers $\alpha-, \beta-, \gamma$ - and $\delta$ of hexachlorocyclohexane $(\mathrm{HCH})$ in sterilized and infested soil employing the white rot fungi Phanerochaete chrysosporium (left) and Bjerkandera adusta (right) after $35 \mathrm{~d}$ of treatment. Soil was infested with inoculated corncobs (A) and inoculated woodchips (B). White bars = abiotic controls and grey bars = fungal treatment.

P. chrysosporium indicate variable degradation rates ranging from $10.6 \%$ (Arisoy, 1997) to $90 \%$ (Singh and Kuhad, 1999) with mineralization values ranging from $3.9 \%$ (Mougin et al., 1996) to more than 90\% (Bumpus et al., 1985).

Our results show $42 \%$ degradation of $\gamma-\mathrm{HCH}$ with B. adusta in liquid medium and 8 to $17 \%$ degradation of the same isomer with the same fungi in a sandy soil system. Mass transfer effects limit the accessibility of $\mathrm{HCH}$ in soil compared to liquid media (Mougin et al., 1997).

In the degradation of lindane, intermediate metabolites such as tetrachlorocyclohexene (TCCH) and tetrachlorocyclohexenol (TCCOL) have been detected previously (Singh and Kuhad, 2000; Mougin et al., 1996). However, these compounds were not detected in this work. Instead, organochloride compounds such as ethanone 1-(3-chloro-4-methoxyphenyl)- and 1-benzenecarbonyl chloride, 2,4-dichloro-3methoxy were detecteddue tofungal biosynthetic capacity. The endogenous production of these two compounds as secondary metabolites was previously reported (Mester et al., 1997; Field et al., 1995). The biosynthetic routes of the organochlorine metabolites are still unknown. It is hypothesized that the humus or other organic material provide chlorine atoms required for metabolite formation (Silk et al., 2001). In this study, the degradation of $\mathrm{HCH}$ provides a possible supply source for these chlorine atoms. However additional experimentation will be needed to prove this hypothesis.

To increase the levels of degradation in soil, some researchers have inoculated polluted soils with various fungal species immobilized on different lignocellulosic supports (e.g., woodchips, corncobs, and wheat straw) (Andersson and Henrysson, 1996; Kennedy et al., 1990). These reports show the beneficial effect of immobilization on degradation of organic cyclic compounds. The white rot fungus $P$. chrysosporium immobilized in corncobs achieved 35\% degradation of TNT after $18 \mathrm{~d}$ of treatment (Tudor et al., 1990), 62\% degradation of 2,4,5-trichlorophenoxyacetic acid after $30 \mathrm{~d}$ of treatment (Ryan and Bumpus, 1989), $10 \%$ degradation of DDT after $60 \mathrm{~d}$ treatment (Bumpus et al., 1988), and 23\% degradation of chlordane after $60 \mathrm{~d}$ of treatment (Kennedy et al., 1990). 
Table 2. Biodegradation of hexachlorocyclohexane $(\mathrm{HCH})$ isomers in sandy soil infested with Bjerkandera adusta after four weeks of incubation.

\begin{tabular}{|c|c|c|c|c|}
\hline \multirow[b]{2}{*}{ Systems } & \multicolumn{4}{|c|}{$\mathrm{HCH}$ isomers degraded ${ }^{1}, \%$} \\
\hline & $\alpha-\mathrm{HCH}$ & $\beta-\mathrm{HCH}$ & $\gamma-\mathrm{HCH}$ & $\delta-\mathrm{HCH}$ \\
\hline \multicolumn{5}{|l|}{ Infested soil: } \\
\hline Corncobs + sterile soil & $15.9 \pm 4.7$ & $13.8 \pm 4.1$ & $17.4 \pm 4.4$ & $15.7 \pm 5.1$ \\
\hline Woodchips + sterile soil & $10.1 \pm 3.7$ & $14.5 \pm 8.1$ & $8.2 \pm 5.3$ & $17.5 \pm 9.0$ \\
\hline Woodchips + Non sterile soil & $12.1 \pm 5.4$ & 0.0 & $62.0 \pm 4.6$ & 0.0 \\
\hline \multicolumn{5}{|l|}{ Non infested soil: } \\
\hline Non sterilized soil & $16.1 \pm 2.7$ & 0.0 & $62.8 \pm 8.5$ & 0.0 \\
\hline
\end{tabular}

${ }^{1}$ Each value is the mean of three replicates \pm standard deviation.

Plant residues are a plentiful source of nutrients that favor fungal growth and soil colonization. Additionally, plant residues elicit production of adaptative ligninolytic enzymes (Castillo et al., 2001; Fujian et al., 2001). However, the lower remediation values obtained in soil than liquid medium can be explained by sorption phenomena. Pollutant is retained in the soil pores thereby impeding transfer to the liquid phase (Quintero et al., 2005; Rijnaarts et al., 1990).

Synergistic effects between white rot fungi and other soil microorganisms were not observed in this study. In contrast, the fungi showed no elimination of $\alpha$ - and $\gamma-\mathrm{HCH}$ in the presence of soil microorganisms. Several white-rot fungi species show potential for possible use in bioremediation of $\mathrm{HCH}$ isomers. A similar effect was found in degradation of benzo[a]pyrene by $B$. adusta in the soil in presence of indigenous microflora (Kotterman and Field, 1998; Wiesche, et al., 1996).

In conclusion, several white-rot fungi species have demonstrated a high capacity to degrade organic pollutants such the insecticide lindane $(\gamma-\mathrm{HCH})$. The $\delta$ - and $\gamma-\mathrm{HCH}$ isomers were between 15.1 to $70.8 \%$ degraded by $B$. adusta, $P$. ciliatus, L. tigrinus, $S$. hirsutum, $P$. eryngii and I. lacteus, while $\beta-\mathrm{HCH}$ was 56.6, 26.5 and $23.9 \%$ degraded by $B$. adusta, P. ciliatus and $P$. eryngii, respectively. In non-sterile soil, $B$. adusta, immobilized on corncobs or woodchips, all the $\mathrm{HCH}$ isomers were from 8.2 to $17.5 \%$ degraded. In a non-sterile soil, an antagonist effect with the soil microflora was observed.
This effect could be avoided by increasing the fungal biomass in the inoculation step.

\section{Resumen}

Los hongos de la pudrición blanca de la madera han demostrado una alta capacidad para degradar contaminantes orgánicos $\mathrm{y}$ entre ellos el insecticida lindane $(\gamma-\mathrm{HCH})$. Sin embargo, no se conoce su capacidad para degradar los demás isómeros presentes en la formulación de este insecticida, altamente tóxico y recalcitrante en el ambiente. El objetivo de este estudio fue evaluar la sensibilidad de diferentes especies de hongos de la pudrición blanca de la madera a los isómeros de $\alpha-, \beta$-, $\gamma-$ y $\delta$ de hexachlorociclohexane $(\mathrm{HCH})$, así como su capacidad para degradarlos en medios líquidos y sólidos. Los hongos evaluados fueron: Bjerkandera adusta, Irpex lacteus, Lentinus tigrinus, Phanerochaete chrysosporium, Phanerochaete sordida, Phlebia radiata, Pleurotus eryngii, Poliporus cialatus y Stereum hirsutum. Los resultados mostraron que $\delta$ - y $\gamma$-HCH fueron los isómeros que presentaron mayor grado de inhibición en el crecimiento a concentraciones entre 5 y $10 \mathrm{mg} \cdot \mathrm{L}^{-1}$. Además, $P$. chrysosporium and $B$. adusta fueron los que mostraron mayor tolerancia a altas concentraciones de los contaminantes. Los isómeros $\delta$ - and $\gamma-\mathrm{HCH}$ fueron considerablemente degradados en medio líquido entre 15,1 and $70,8 \%$ por $B$. adusta, $P$. ciliatus, L. tigrinu, S. hirsutum, $P$. eryngii and $I$. lacteus. Mientras que $\beta-\mathrm{HCH}$ solamente fue degradado por $B$. adusta, $P$. ciliatus and $P$. eryngii, en proporciones de 56,6; 26,5 and 
23,9\%, respectivamente. En suelo esterilizado B. adusta degradó parcialmente todos los isómeros entre 8,2 and $17,5 \%$, mientras que en suelo no esterilizado se observó un efecto antagonista que impidió la acción del hongo.

Palabras clave: Bjerkandera adusta, lindano, hongos de la madera, pesticidas.

\section{References}

Alexander, M. 1981. Biodegradation of chemicals of environmental concern. Science 211:132-138.

Alleman, B.C., B.E., Logan, and R.L. Gilbertson. 1992. Toxicity of pentachlorophenol to six species of white rot fungi as a function of chemical dose. Applied and Environmental Microbiology 58:4048-4050.

Andersson, B.E., and T. Henrysson. 1996. Accumulation and degradation of deadend metabolites during treatment of soil contaminated with polycyclic aromatic hydrocarbons with five strains of white-rot fungi. Applied Microbiology and Biotechnology 46:647-652.

Arisoy, M. 1998. Biodegradation of chlorinated organic compounds by white-rot fungi. Bulletin of Environmental Contamination and Toxicology 60:872-876.

Arisoy, M., and N. Kolankaya. 1997. Biodegradation of lindane by Pleurotus sajor-caju and toxic effects of lindane and its metabolites on mice. Bulletin of Environmental Contamination and Toxicology 59:352-359.

Aust, D., and J. Benson. 1993. The fungus among Us: Use of white rot fungi to biodegrade environmental pollutants. Environmental Health Perspectives 101:1-3.

Bachmann, A., P. Walet, P. Wijnen, W. de Bruin, J. L. Huntjens, W. Roelofsen, and A.J. Zehnder. 1988. Biodegradation of alpha- and betahexachlorocyclohexane in a soil slurry under different redox conditions. Applied and Environmental Microbiology 54:143-149.

Barr, D.P., and S.D. Aust. 1994. Mechanisms white-rot fungi use to degrade pollutants. Environmental Science and Technology 28:78A-87A.

Breivik, K., J.M. Pacyna, and J. Münch. 1999. Use of alfa-, beta- and gamma-hexachlorocyclohexane in Europe, 1970-1996. Science of the Total Environment 239:151-163.

Bucke, C. 1998. Biochemistry of bioremediation of fungi. Journal of Chemical Technology and Biotechnology 71:356-357.

Bumpus, J.A., M. Tien, D. Wright, and S.D. Aust.
1985. Oxidation of persistent environmental pollutants by a white rot fungus. Science 228:1434-1436.

Bumpus, J.A., F. Tudor, M.A. Jurek, and S.D. Aust. 1988. Factors affecting biodegradation of xenobiotics by the white rot fungus Panerochaete chrysosporium. Pages 363-381. In: Engineering Foundation. Biotechnology Applications in Hazardous Waste Treatment. NY, USA.

Castillo, M., A. Andersson, P. Ander, J. Stenström, and L. Torstensson. 2001. Establishment of the white rot fungus Phanerochaete chrysosporium on unsterile straw in solid substrate fermentation systems intended for degradation of pesticides. World Journal of Microbiology and Biotechnology 17:627-633.

Couto, S.R., G. Feijoo, M.T. Moreira, and J.M. Lema. 2002. Evaluation of the environmental conditions for the continuous production of lignin peroxidase by Phanerochaete Chrysosporium in fixed-bed bioreactors. Biotechnology Letters 24:791-794.

Field, J.A., E. de Jong, G. Feijoo, and J.A.M. de Bont. 1993. Screening for Ligninolytic Fungi Applicable to the Biodegradation of Xenobiotics. Trends in Biotechnology 11:44-49.

Field, J.A., F.J.M. Verhagen, and E.D. de Jong. 1995. Natural organohalogen production by basidiomycetes. Trends in Biotechnology 13:451-456.

Fujian, X., C. Hongzhang, and L. Zuohu. 2001. Solid-state production of lignin peroxidase (LiP) and manganese peroxidase (MnP) by Phanerochaete chrysosporium using steamexploded straw as substrate. Bioresource Technology 80:149-151.

Kennedy, D., S. Aust, and A. Bumpus. 1990. Comparative biodegradation of alkyl halide insecticides by the white rot fungus, Phanerochaete chrysosporium (BKM-F-1767). Applied and Environmental Microbiology 56:2347-2353.

Kotterman, M., E. Vis, and J. Field. 1998. Successive mineralization and detoxification of benzo[a]pyrene by the white rot fungus Bjerkandera sp. strain BOS55 and indigenous microflora. Applied and Environmental Microbiology 64:2853-2858.

Li,Y.F.1999.Globaltechnicalhexachlorocyclohexane usage and its contamination consequences in the environment: from 1948 to 1997. Science of the Total Environment 232:121-158.

Macrae, I.C., Y. Yamaya, and T. Yoshida. 1984. Persistence of hexachlorocyclohexane isomers in soil suspensions. Soil Biology and Biochemistry 16:285-286. 
Masaphy, S., Y. Henis, and D. Levanon. 1996. Manganese-enhanced biotransformation of atrazine by the white rot fungus Pleurotus pulmonarius and its correlation with oxidation activity. Applied and Environmental Microbiology 62:3587-3593.

Mester, T., H.J. Swarts, S. Sole, J.A. de Bont, and J.A. Field. 1997. Stimulation of aryl metabolite production in the basidiomycete Bjerkandera $s p$. strain BOS55 with biosynthetic precursors and lignin degradation products. Applied and Environmental Microbiology 63:1987-1994.

Mester, T., and M. Tien. 2000. Oxidation mechanism of ligninolytic enzymes involved in the degradation of environmental pollutants. International Biodeterioration and Biodegradation 46:51-59.

Moreira, M.T., G. Feijoo, and J.M. Lema. 2000. Manganese peroxidase production by Bjerkandera sp. BOS55. 1. Regulation of enzymatic production. Bioprocess and Biosystems Engineering 23:657-661.

Mougin, C., C. Pericaud, J. Dubroca, and M. Asther. 1997. Enhanced mineralization of lindane in soils supplemented with the white rot basidiomycete Phanerochaete chrysosporium. Soil Biology and Biochemistry 29:1321-1324.

Mougin, C., C. Pericaud, C. Malosse, C. Laugero, and M. Asther. 1996. Biotransformation of the insecticide lindane by the white rot basidiomycete Phanerochaete chrysosporium. Pesticide Science 47:51-59.

Quintero, J.C., G. Feijoo, and J.M. Lema. 2006a. Producción de enzimas ligninolíticas con hongos basidiomicetos por fermentación en estado sólido. Vitae 13:61-67

Quintero, J.C., M.T. Moreira, J.M. Lema, and G. Feijoo. 2006b. An anaerobic bioreactor allows the efficient degradation of $\mathrm{HCH}$ isomers in soil slurry. Chemosphere 63:1005-1013.

Quintero, J.C., M.T. Moreira, J.M. Lema, and G. Feijoo. 2005. Effect of surfactants on the soil desorption and anaerobic biodegradation of hexachlorocyclohexane $(\mathrm{HCH})$ isomers. Journal of Chemical Technology and Biotechnology 80:1005-1015
Reddy, G.V.B., M.D.S. Gelpke, and M.H. Gold. 1998. Degradation of 2,4,6-trichlorophenol by Phanerochaete chrysosporium: Involvement of reductive dechlorination. Journal of Bacteriology 180:5159-5164.

Rijnaarts, H., A. Bachmann, J. Jumelet, and A. Zehnder. 1990. Effect of desorption and intraparticule mass transfer on the aerobic biomineralization of alfahexachlorocyclohexane in a contaminated calcareous soil. Environmental Science and Technology 24:1349-54.

Ryan, T.P., and J.A. Bumpus. 1989. Biodegradation of 2,4,5- trichlorophenoxyacetic acid in liquid culture and in soil by the white rot fungus Phanerochaete chrysosporium. Applied Microbiology and Biotechnology 31:302-307.

Silk, P.J., C. Aubry, G.C. Lonergan, and J.B. Macaulay. 2001. Chlorometabolite production by the ecologically important white rot fungus Bjerkandera adusta. Chemosphere 44:16031616.

Singh, B.K., and R.C. Kuhad. 1999. Biodegradation of lindane (gamma-hexachlorocyclohexane) by the white-rot fungus Trametes hirsutus. Letters in Applied Microbiology 28:238-241.

Singh, B.K., and R.C. Kuhad. 2000. Degradation of insecticide lindane (gamma-HCH) by whiterot fungi Cyathus bulleri and Phanerochaete sordida. Pest Management Science 56:142-146.

Tien, M., and T.K. Kirk. 1988. Lignin peroxidase of Phanerochaete chrysosporium. Pages 238-249. In: W. Wood, and S.T. Kellog (eds.). Methods Enzymology. vol. 161, Academic Press, Inc., London.

Tudor, F., J. Bumpus, and S. Aust. 1990. Biodegradation of TNT (2,4,6-trinitrotoluene) by Phanerochaete chrysosporium. Applied and Environmental Microbiology 56:1666-1671.

Wiesche, C., R. Martens, and F. Zadrazil. 1996. Two-Step degradation of pyrene by whiterot fungi and soil microorganisms. Applied Microbiology and Biotechnology 46:653-659.

Willett, K.L., E.M. Ulrich, and R.A. Hites. 1998. Differential toxicity and environmental fates of hexachlorocyclohexane isomers. Environmental Science and Technology 32:2197-2207. 